\title{
Comparative Analysis of Cloud Simulators and Authentication Techniques in Cloud Computing
}

\author{
Ashima Mehta, S. N. Panda \\ Research Scholar, Chitkara University, Punjab, India. \\ Director Research, CURIN, Chitkara University Punjab, India. \\ Published Online: December 28, 2016 \\ The Author(s) 2016. This article is published with open access at www.chitkara.edu.in/publications
}

\begin{abstract}
Cloud computing is the concern of computer hardware and software resources above the internet so that anyone who is connected to the internet can access it as a service or provision in a seamless way. As we are moving more and more towards the application of this newly emerging technology, it is essential to study, evaluate and analyze the performance, security and other related problems that might be encountered in cloud computing. Since, it is not a practicable way to directly examine the behavior of cloud on such problems using the real hardware and software resources due to its high costs, modeling and simulation has become an essential tool to withstand with these issues. In this paper, we retrospect, analyse and compare features of the existing cloud computing simulators and various location based authentication and simulation tools.
\end{abstract}

Keywords: Cloud Computing; CloudSim; CDOSim; TeachCloud; iCanCloud; SPECI; GroudSim; DCSim, Kerbos

\section{INTRODUCTION}

Cloud computing is a assemblage of on hand techniques and technologies, packaged within a new and highly scalable infrastructure paradigm that offers improved scalability, elasticity, business agility, faster startup time, reduced management costs, and just-in-time availability of resources [1].

From the past few years, there has been a hasty progress in Cloud Computing. It delivers an extensive range of resources like computational platforms, computational power, storage and applications to users via internet. The foremost Cloud providers in the current market segment are Amazon, Google, IBM, Microsoft, Salesforce, etc. [2]. With an ever-increasing number of companies resorting to use resources in the Cloud, there is a necessity for protecting the data of various users. Some major challenges that are being faced by Cloud Computing Journal on Today's Ideas Tomorrow's Technologies, Vol. 4, No. 2, December 2016 pp. 181-191 are to secure, protect and process the data which is the property of the user.

\section{CLOUD SIMULATORS}

While grid computing simulators have good but they cannot sufficiently model the cloud infrastructure. There are still only a few options for

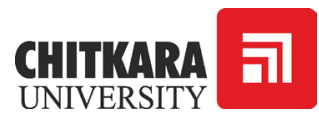


Mehta, A.

Panda, S. N.

simulating cloud architecture, possibly because virtualization has enabled the deployment of virtual private clouds on small scale physical test beds. However, there have been some notable proposals for software simulation of clouds of very large scale. The CloudSim simulation framework is based on the SimJava discrete event simulation engine at the lowest layer, while the higher layers implement the GridSim toolkit for the modeling of the cluster, including networks, traffic profiles, resources, etc. CloudSim effectively extends the GridSim core functionalities by modeling storage, application services, resource provisioning between virtual machines, and data centre brokerage, and can even simulate federated clouds $[2,3]$.

\section{A. CloudSim}

CloudSim is an extensible simulation toolkit and application which promotes and enhances seamless modeling, extensive simulation, and experimentation of emerging cloud computing environment, infrastructures and application environments for single and many internetworked clouds [3, 4]. The existing distributed system simulators were not applicable to the cloud environment due to evaluating the performance of cloud provisioning policies, services, application workload, models and resources under varying system, user configurations and requirements. To overcome this challenge, CloudSim can be used. In simple words, CloudSim is a development toolkit for simulation of Cloud scenarios. CloudSim is not a framework as it does not provide a ready to use environment for execution of a complete scenario with a specific input. Instead, users of CloudSim have to develop the Cloud scenario it wishes to evaluate, define the required output, and provide the input parameters.

\section{B. CDOSim}

CDOSim is cloud deployment option (CDO) Simulator which can simulate the response times, SLA violations and costs of a CDO. CDOSim is designed to concentrate on the major shortcomings of other existing cloud simulators such as

1. Subsequently oriented towards the cloud user perspective instead of exposing fine-grained internals of a cloud platform [5].

2. Mitigates the cloud user's lack of knowledge and control concerning a cloud platform structure.

\section{TeachCloud}

TeachCloud is a cloud simulator which is specially made for education purposes. TeachCloud provides a simple graphical interface through which students and 
scholars can modify a cloud's configuration and perform simple experiments [8]. TeachCloud uses CloudSim as the basic design platform and introduces many new enhancements on top of it such as

1. Developing a GUI toolkit.

2. Adding the cloud workload generator to the CloudSim simulator.

3. Adding new modules related to SLA and BPM.

4. Adding new cloud network models such as VL2, BCube, Portland and DCell.

\section{D. iCan}

Cloud is a cloud simulator which is based on SIMCAN. In simple words, iCanCloud is a software simulation framework for large storage networks. iCanCloud can predict the trade-off between costs and performance of a particular application in a specific hardware in order to inform the users about the costs involved[1,9].

\section{E. SPECI}

Simulation Program for Elastic Cloud Infrastructures (SPECI) is a simulation tool which allows analyzing and exploration of scaling properties of large data center behavior under the size and design policy of the middleware as inputs. SPECI is a simulation tool which allows exploration of aspects of scaling as well as performance properties of future Data Centers [10]. The aim of SPECI is to simulate the performance and behavior of data centers, given the size and middleware design policy as input. Discrete event simulations (DES) are a type of simulation where events are ordered in time maintained in a queue of events by the simulator and each processed at given simulation time.

\section{Authentication Techniques}

Cloud service providers request customers to store their account information in the cloud, cloud service providers have the access to this information. This presents a privacy issue to the customer's privacy information. Cloud service providers use different authentication technologies for authenticating users. This process serves as a protection against different sorts of attacks where the goal is to confirm the identity of a user and the user requests services from cloud servers. Multiple authentication technologies have been put forward so far that confirm user identity before giving the permit to access resources.
Comparative Analysis of Cloud Simulators and Authentication Techniques in Cloud Computing 
Mehta, A.

Panda, S. N.
REVIEW OF LITERATURE

\begin{tabular}{|c|c|c|c|c|c|c|}
\hline $\begin{array}{l}\text { Sr. } \\
\text { No. }\end{array}$ & $\begin{array}{c}\text { Year of } \\
\text { publica- } \\
\text { tion }\end{array}$ & Author & Title & Journal & Listing & Findings of the study \\
\hline 1. & 2012 & $\begin{array}{l}\text { Debabrata } \\
\text { Dey, Atanu } \\
\text { Lahiri, and } \\
\text { Guoying } \\
\text { Zhang }\end{array}$ & $\begin{array}{l}\text { Hacker } \\
\text { Behaviour, } \\
\text { Network Ef- } \\
\text { fects, and the } \\
\text { Security Soft- } \\
\text { wre Market }\end{array}$ & $\begin{array}{l}\text { Journal of } \\
\text { Management } \\
\text { Information } \\
\text { Systems }\end{array}$ & $\mathrm{ABDC}$ & $\begin{array}{l}\text { 1. There are neg- } \\
\text { ative network } \\
\text { effect from indi- } \\
\text { rect attacks and } \\
\text { positive network } \\
\text { effect from vul- } \\
\text { nerability-based } \\
\text { attacks [1]. } \\
\text { 2. Consequent- } \\
\text { ly there is a } \\
\text { negative network } \\
\text { effect from } \\
\text { strategic hacker } \\
\text { behavior [1]. }\end{array}$ \\
\hline 2. & 2013 & $\begin{array}{l}\text { Vidyanand } \\
\text { Choudhary } \\
\text { and Joseph } \\
\text { Vithayathil }\end{array}$ & $\begin{array}{l}\text { The Impact } \\
\text { of Cloud } \\
\text { Computing: } \\
\text { Should } \\
\text { the IT De- } \\
\text { partment Be } \\
\text { Organized as a } \\
\text { Cost Center } \\
\text { or a Profit } \\
\text { Center? }\end{array}$ & $\begin{array}{l}\text { Journal of } \\
\text { Management } \\
\text { Information } \\
\text { Systems }\end{array}$ & ABDC & $\begin{array}{l}\text { 1. The stylized mod- } \\
\text { el is employed } \\
\text { to analyze the } \\
\text { impact of cloud } \\
\text { computing on } \\
\text { the choice of } \\
\text { organizational } \\
\text { structure for the } \\
\text { IT department by } \\
\text { making simplify- } \\
\text { ing assumptions } \\
\text { [2]. } \\
\text { The mission of } \\
\text { the IT department } \\
\text { would transition } \\
\text { to determining the } \\
\text { means by which } \\
\text { the IT personnel } \\
\text { can ensure that } \\
\text { enhancements } \\
\text { to cloud-based } \\
\text { services fit the } \\
\text { current and future } \\
\text { needs of the con- } \\
\text { suming units [2]. }\end{array}$ \\
\hline 3. & 2014 & $\begin{array}{l}\text { A.K. R. } \\
\text { Parveen } \\
\text { Kumar }\end{array}$ & $\begin{array}{l}\text { An overview } \\
\text { and survey of } \\
\text { various } \\
\text { cloud simula- } \\
\text { tion tools }\end{array}$ & $\begin{array}{l}\text { Journal of } \\
\text { Global Research } \\
\text { in Computer } \\
\text { Science }\end{array}$ & $\mathrm{ABDC}$ & $\begin{array}{l}\text { 1. Detailed analyt- } \\
\text { ical and com- } \\
\text { parative analysis } \\
\text { of various cloud } \\
\text { simulators used } \\
\text { in the world of } \\
\text { cloud computing } \\
\text { [1]. }\end{array}$ \\
\hline
\end{tabular}




\begin{tabular}{|c|c|c|c|c|c|c|}
\hline 4. & 2014 & $\begin{array}{l}\text { Poonam M. } \\
\text { Pardeshi, } \\
\text { Prof. Bharat } \\
\text { Tidke }\end{array}$ & $\begin{array}{l}\text { Improving } \\
\text { Data Integrity } \\
\text { for Data Stor- } \\
\text { age Security } \\
\text { in Cloud } \\
\text { Computing }\end{array}$ & $\begin{array}{l}\text { International } \\
\text { Journal of Com- } \\
\text { puter Science } \\
\text { and Information } \\
\text { Technologies }\end{array}$ & --------- & $\begin{array}{l}\text { 1. A secured and } \\
\text { efficient AES } \\
\text { based system has } \\
\text { been proposed for } \\
\text { auditing user data } \\
\text { stored at un-trust- } \\
\text { ed server [7]. } \\
\text { 2. The system guar- } \\
\text { antees data the } \\
\text { achievement of } \\
\text { data integrity and } \\
\text { availability [7]. }\end{array}$ \\
\hline 5. & 2014 & $\begin{array}{l}\text { Jashanpreet } \\
\text { Pal Kaur, } \\
\text { Rajbhupin- } \\
\text { der Kaur }\end{array}$ & $\begin{array}{l}\text { Multilayered } \\
\text { Security } \\
\text { Approach for } \\
\text { Cloud Data } \\
\text { Centers using } \\
\text { Hash Func- } \\
\text { tions }\end{array}$ & $\begin{array}{l}\text { International } \\
\text { Journal of } \\
\text { Science and Re- } \\
\text { search (IJSR) }\end{array}$ & -------- & $\begin{array}{l}\text { 1. The dynamic hash } \\
\text { keys are generated } \\
\text { for the authentica- } \\
\text { tion purpose using } \\
\text { hybrid approach } \\
\text { [11]. } \\
\text { 2. The cloud data } \\
\text { centers are } \\
\text { accessed by au- } \\
\text { thenticated clients } \\
\text { using secured shell } \\
\text { and encrypted } \\
\text { transmission via } \\
\text { brokers. If the } \\
\text { client's authenti- } \\
\text { cation failed then } \\
\text { it terminates the } \\
\text { execution [11]. }\end{array}$ \\
\hline 6. & 2014 & $\begin{array}{l}\text { G. Vi- } \\
\text { jayanand } \\
\text { et al. }\end{array}$ & $\begin{array}{l}\text { Overcome } \\
\text { vampire at- } \\
\text { tacks problem } \\
\text { in wireless ad- } \\
\text { hoc sensor net- } \\
\text { work by using } \\
\text { distance vector } \\
\text { protocols }\end{array}$ & $\begin{array}{l}\text { International } \\
\text { Journal of Com- } \\
\text { puter Science } \\
\text { and Mobile } \\
\text { Applications } \\
\text { Vol.2 Issue. } 1 \\
\text { ISSN: } 2321 \text { - } \\
8363\end{array}$ & --------- & $\begin{array}{l}\text { 1. Guarantee Loop } \\
\text { Freeness [13] } \\
\text { 2. Allow fast reaction } \\
\text { to topology chang- } \\
\text { es [13]. }\end{array}$ \\
\hline 7. & 2012 & $\begin{array}{l}\text { Jie Liu, } \\
\text { Bodhi Pri- } \\
\text { yantha, Ted } \\
\text { Hart, Heitor } \\
\text { S. Ramos, } \\
\text { Antonio A.F. } \\
\text { Loureiro }\end{array}$ & $\begin{array}{l}\text { Energy } \\
\text { Efficient } \\
\text { GPS Sensing } \\
\text { with Cloud } \\
\text { Offloading }\end{array}$ & $\begin{array}{l}\text { SenSys'12, } \\
\text { Copyright c } \\
\text { 2012 ACM 978- } \\
\text { 1-4503-1169-4 }\end{array}$ & $\mathrm{ABDC}$ & $\begin{array}{l}\text { 1. Evaluates the qual- } \\
\text { ity and limitations } \\
\text { of the CO-GPS } \\
\text { approach using } \\
\text { raw GPS samples } \\
\text { [17]. } \\
\text { 2. The use of CTN } \\
\text { technique adds ad- } \\
\text { ditional potential } \\
\text { error, especially } \\
\text { when the number } \\
\text { of satellites is low } \\
\text { [17]. }\end{array}$ \\
\hline
\end{tabular}

Comparative Analysis of Cloud Simulators and Authentication Techniques in Cloud Computing 
Mehta, A.

Panda, S. N.

\begin{tabular}{|c|c|c|c|c|c|c|}
\hline 8. & 2015 & Raj kumar & $\begin{array}{l}\text { Research on } \\
\text { cloud comput- } \\
\text { ing security } \\
\text { threats using } \\
\text { data transmis- } \\
\text { sion }\end{array}$ & $\begin{array}{l}\text { International } \\
\text { journal of Ad- } \\
\text { vanced Research } \\
\text { in Computer } \\
\text { Science \& S/W } \\
\text { Engineering } \\
\text { Vol5 Issue1 } \\
\text { ISSN:2277 }\end{array}$ & ......... & $\begin{array}{l}\text { 1. Both the Service } \\
\text { providers and the } \\
\text { clients must work } \\
\text { together to ensure } \\
\text { safety and security } \\
\text { of cloud and data } \\
\text { on clouds [18]. } \\
\text { 2. This study iden- } \\
\text { tifies top security } \\
\text { concerns of cloud } \\
\text { computing, these } \\
\text { concerns are Data } \\
\text { loss, Leakage of } \\
\text { Data, Client's } \\
\text { trust, User's } \\
\text { Authentication, } \\
\text { Malicious users } \\
\text { handling, Wrong } \\
\text { usage of Cloud } \\
\text { computing and its } \\
\text { services [18]. }\end{array}$ \\
\hline 9. & 2015 & $\begin{array}{l}\text { R. Ve- } \\
\text { lumadhava } \\
\text { Raoa,, K. } \\
\text { Selvamanib, }\end{array}$ & $\begin{array}{l}\text { Data Security } \\
\text { Challenges and } \\
\text { Its Solutions } \\
\text { in Cloud Com- } \\
\text { puting }\end{array}$ & $\begin{array}{l}\text { International } \\
\text { Conference } \\
\text { on Intelligent } \\
\text { Computing, } \\
\text { Communication } \\
\text { \& Convergence }\end{array}$ & $\begin{array}{l}\text { Elsevi- } \\
\text { er }\end{array}$ & $\begin{array}{l}\text { 1. Proper key } \\
\text { management tech- } \\
\text { niques can be used } \\
\text { to distribute the } \\
\text { key to the cloud } \\
\text { users such that } \\
\text { only authorized } \\
\text { persons can access } \\
\text { the data [25]. } \\
\text { 2. To provide a } \\
\text { secure data access } \\
\text { in cloud, advanced } \\
\text { encryption } \\
\text { techniques can be } \\
\text { used for storing } \\
\text { and retrieving data } \\
\text { from cloud. }\end{array}$ \\
\hline 10. & 2014 & $\begin{array}{l}\text { Monjur } \\
\text { Ahmed \& } \\
\text { Mohammad } \\
\text { Ashray }\end{array}$ & $\begin{array}{l}\text { Cloud com- } \\
\text { puting and } \\
\text { security issues } \\
\text { in the cloud }\end{array}$ & $\begin{array}{l}\text { International } \\
\text { Journal of Net- } \\
\text { work Security \& } \\
\text { Its Applications } \\
\text { (IJNSA), Vol.6, } \\
\text { No.1, January } \\
2014\end{array}$ & --------- & $\begin{array}{l}\text { 1. Cloud computing } \\
\text { is a great opportu- } \\
\text { nity and lucrative } \\
\text { option both to the } \\
\text { businesses and the } \\
\text { attackers [32]. } \\
\text { 2. The vastness and } \\
\text { potentiality of } \\
\text { cloud Computing } \\
\text { cannot be over- } \\
\text { looked, subse- } \\
\text { quently robust } \\
\text { security models } \\
\text { for cloud com- } \\
\text { puting scenarios } \\
\text { is the most prior- } \\
\text { itized factor for a } \\
\text { successful cloud } \\
\text { based infrastruc- } \\
\text { ture development } \\
\text { and deployment. }\end{array}$ \\
\hline
\end{tabular}




\section{RESEARCH METHODOLOGY}

1) Simulation Engine (Several simulators have been specifically developed for performance analysis of cloud computing environments [1], including CloudSim, GreenSim, SPECI, GROUDSIM, and DCSim).

2) Spreadsheet Plug-ins for parameter analysis

3) Implementation of cryptography and secured layered in the proposed algorithmic approach [11].

4) CloudSim or relevant simulator is a toolkit for the modeling and simulation of Cloud computing environments.

5) Enabling Public Audit ability and Data Dynamics for Storage Security in Cloud Computing can be done where the third party auditor (TPA), who has expertise and capabilities that cloud users do not have and is trusted to assess the cloud storage service security on behalf of the user upon request $[13,15]$. In addition to this various authentication techniques and parameters have been discussed further.

\section{EXPECTED CONTRIBUTIONS OF PH.D. WORK}

Security is the main concern for cloud computing and also choosing the comprehensive simulator for simulation is desired. Thus various authentication techniques will be compared and analysed along with various cloud simulators. Authentication can be done in various ways:

- Authentication using Kerberos.

- Authentication using Key Distribution Centre.

- Authentication using Public Key Infrastructure.

\section{A. Authentication using Kerberos}

Kerberos is the authentication technique which is used to authenticate the clients to the server in the Client-Server architecture model. Cloud Computing can also be viewed as distributed Client-Server architecture, where Cloud Provider is the Server and Cloud User is the Client., which communicates by the intermediater, named as Cloud Broker. The two main components areTicket Granting Server and Authentication Server [16].

(1) Cl ASS: IDC $\mid$ PC || IDV

(2) AS Cl Ticket

(3) C Z: IDCl||Ticket

Ticket $=\mathrm{E}(\mathrm{Kv},[\mathrm{IDC}\|\mathrm{ADC}\| \mathrm{IDZ}])$

Where

$\mathrm{Cl}=\mathrm{Client}$

ASS $=$ Authentication System Server
Comparative

Analysis of Cloud Simulators and

Authentication

Techniques in

Cloud Computing 


\section{Mehta, A. $\quad Z=$ Server \\ Panda, S. N. $\quad$ IDC=Identifier of user on $\mathrm{Cl}$ \\ IDZ=Identifier of Server \\ $\mathrm{PC}=$ Password of user on $\mathrm{Cl}$. \\ $\mathrm{ADC}=$ Network Address of $\mathrm{Cl}$ \\ $\mathrm{KV}=$ Secret Encryption key shared by ASS and Z}

\section{B. Authentication using Key Distribution Centre}

$\mathrm{A}$ issues a request to the KDC for a session key to shield a logical connection to $\mathrm{B}$. This message includes the distinctiveness of A and $\mathrm{B}$ and a exceptional or unique identifier, $\mathrm{N} 1$, for this transaction, which we refer to as a nonce The nonce might be a counter, a timestamp, or a random number; the minimum requisite is that it differs with each request. Also, to prevent masquerade, it should be difficult for an opponent to guess the nonce. Thus, a random number is a good choice for a nonce. The KDC responds with a message encrypted using Ka Thus, A is the only one who can successfully read the message, and A knows that it originated at the KDC. The message includes two items intended for A:

1. The one-time session key, Ks, to be used for the session.

2. The original request message, including the nonce, to enable $\mathrm{A}$ to match this response with the appropriate request Thus, A can verify that its original request was not altered before reception by the KDC and, because of the nonce, that this is not a replay of some previous request. In addition, the message includes two items intended for B:

3. The one-time session key, Ks to be used for the session

4. An identifier of A (e.g., its network address), IDA

5. These last two items are encrypted with $\mathrm{Kb}$ (the master key that the KDC shares with B). They are to be sent to B to establish the connection and prove A's identity. A stores the session key for use in the upcoming session and forwards to $\mathrm{B}$ the information that originated at the $\mathrm{KDC}$ for $\mathrm{B}$, namely, $\mathrm{E}(\mathrm{Kb},[\mathrm{Ks} \| \mathrm{IDA}])$. Because this information is encrypted with $\mathrm{Kb}$, it is protected from eavesdropping. B now knows the session key (Ks), knows that the other party is A (from IDA), and knows that the information originated at the $\mathrm{KDC}$ (because it is encrypted using $\mathrm{Kb}$ ). At this point, a session key has been securely delivered to $\mathrm{A}$ and $\mathrm{B}$, and they may begin their protected exchange. However, two additional steps are desirable:

6. Using the newly minted session key for encryption, B sends a nonce, N2, to A.

7. Also using Ks, A responds with $\mathrm{f}(\mathrm{N} 2)$, where $\mathrm{f}$ is a function that performs some transformation on N2 (e.g., adding one). 


\section{Authentication using Public Key Infrastructure}

The components of PKI are listed below:

8. End entity: A generic term used to denote end users, devices (e.g., servers, routers), or any other entity that can be identified in the subject field of a public key certificate. End entities typically consume and/or support PKIrelated services.

9. Certification authority (CA): The issuer of certificates and (usually) certificate revocation lists (CRLs). It may also support a variety of administrative functions, although these are often delegated to one or more Registration Authorities [17, 18]

10. Registration authority (RA): An optional component that can assume a number of administrative functions from the CA. The RA is often associated with the End Entity registration process, but can assist in a number of other areas as well.

11. CRL issuer: An optional component that a CA can delegate to publish CRLs.

12. Repository: A generic term used to denote any method for storing certificates and CRLs so that they can be retrieved by End Entities. Thus Registration authority is thus dependent on Repository and thus the authentication strategy thus can be embedded [20,22].

\section{MAJOR FINDINGS AND CONCLUSION}

Table1: Comparative analysis of various cloud simulators with respect to different properties

\begin{tabular}{|c|c|c|c|c|c|c|}
\hline $\begin{array}{l}\text { Cloud Simu- } \\
\text { lators }\end{array}$ & Platform & $\begin{array}{l}\text { GUI Sup- } \\
\text { port }\end{array}$ & $\begin{array}{c}\text { Support } \\
\text { of TCP/IP }\end{array}$ & $\begin{array}{l}\text { Language } \\
\text { support- } \\
\text { ed }\end{array}$ & $\begin{array}{l}\text { S/w or } \\
\mathbf{H} / \mathbf{W}\end{array}$ & Availability \\
\hline SPECI & SIMKIT & Limited & None & Java & $\mathrm{s} / \mathrm{w}$ & Open source \\
\hline CLOUDSIM & GRIDSIM & Limited & None & Java & $\mathrm{s} / \mathrm{w}$ & Open source \\
\hline OCT & $\begin{array}{l}\text { D IS T R I B - } \\
\text { U T E D } \\
\text { C L O U D } \\
\text { TESTBED }\end{array}$ & $\begin{array}{l}\text { Limited(via } \\
\text { open cloud } \\
\text { testbed) }\end{array}$ & $\mathrm{Na}$ & $\mathrm{n} / \mathrm{a}$ & Both & $\begin{array}{l}\text { Registration } \\
\text { is needed }\end{array}$ \\
\hline $\begin{array}{l}\text { G R E E N } \\
\text { CLOUD }\end{array}$ & Ns2 & Nam & $\begin{array}{l}\text { Full tcp/ip } \\
\text { support }\end{array}$ & $\mathrm{C}++, \mathrm{otcl}$ & $\mathrm{s} / \mathrm{w}$ & Open source \\
\hline GROUDSIM & $\mathrm{Na}$ & None & $\begin{array}{l}\text { Full tcp/ip } \\
\text { support }\end{array}$ & Java & $\mathrm{s} / \mathrm{w}$ & $\mathrm{Na}$ \\
\hline OPENCIRRUS & $\begin{array}{l}\text { Heteroge- } \\
\text { nous data } \\
\text { centres }\end{array}$ & None & $\mathrm{Na}$ & $\mathrm{Na}$ & $\begin{array}{l}\text { Both } s / w \\
\text { and } h / w\end{array}$ & Open source \\
\hline
\end{tabular}


Mehta, A. Panda, S. N.

\begin{tabular}{|c|c|c|c|c|c|c|}
\hline $\begin{array}{l}\text { N E T W O R K } \\
\text { CLOUDSIM }\end{array}$ & Cloudsim & None & None & Java & $\mathrm{s} / \mathrm{w}$ & Open source \\
\hline EMUSIM & $\begin{array}{l}\text { Aef,cloud- } \\
\text { sim }\end{array}$ & Limited & None & Java & $\mathrm{s} / \mathrm{w}$ & Open source \\
\hline DCSIM & $\mathrm{Na}$ & None & No support & Java & $\mathrm{s} / \mathrm{w}$ & Open source \\
\hline $\begin{array}{l}\text { T E A C H - } \\
\text { CLOUD }\end{array}$ & Cloudsim & Full gui kit & None & $\mathrm{Na}$ & $\mathrm{s} / \mathrm{w}$ & Open source \\
\hline CDOSIM & Cloudsim & None & No support & Java & $\mathrm{s} / \mathrm{w}$ & $\mathrm{Na}$ \\
\hline GDCSIM & Bluetool & $\begin{array}{l}\text { No gui sup- } \\
\text { port }\end{array}$ & None & $\mathrm{C}++/ \mathrm{xml}$ & $\mathrm{s} / \mathrm{w}$ & Open source \\
\hline MDCSIM & Csim & $\begin{array}{l}\text { No gui sup- } \\
\text { port }\end{array}$ & None & $\mathrm{C}++/$ java & $\mathrm{s} / \mathrm{w}$ & Commercial \\
\hline $\begin{array}{l}\text { NE T W O R K - } \\
\text { CLOUDSIM }\end{array}$ & $\begin{array}{l}\text { Only cloud } \\
\text { analyst }\end{array}$ & Grid sim & $\begin{array}{l}\text { Supports } \\
\text { only high } \\
\text { perfor- } \\
\text { m a n c e } \\
\text { computer } \\
\text { applica- } \\
\text { tions }\end{array}$ & Java & $\mathrm{s} / \mathrm{w}$ & $\begin{array}{l}\text { Open } \\
\text { source(ex- } \\
\text { tension of } \\
\text { cloudsim) }\end{array}$ \\
\hline
\end{tabular}

Thus numerous cloud simulation tools have been compared and projected along with their properties with respect to their TCP/IP support, GUI support and other related factors. Hence after analyzing various parameters of different simulators and the fact that cloudsim uses gridsim as platform and Grid computing has emerged as the next-generation parallel and distributed computing that aggregates dispersed heterogeneous resources for solving a range of large-scale parallel applications in science, engineering and commerce it is concluded that CloudSim simulator is probably the most sophisticated and user friendly among the simulators overviewed.

\section{REFERENCES}

1. A. K. R. Parveen Kumar, "An overview and survey of various cloud simulation tools," in Journal of Global Research in Computer Science, vol. 5, no. 1, Dcember 2016.

2. [Online].Available: http://www.cloudbus.org/cloudsim/.

3. I. Sriram, "Speci, a simulation tool exploring cloud-scale data centres," in CloudCom 2009, LNCS 5931, pp. 381-392, vol. 5, no.1, January 2016.

4. [Online]. Available: http://www.isi.edu/nsnam/ns/

5. C. B. J. S. J. M. Robert Grossman, YunhongGu, "The open cloud testbed: a wide area testbed for cloud computing utilizing high performance network services," in GridNets 2009, 2009.

6. M. H. S. Y. K. M. K. Roy Cambpell, Indranil Gupta, "Open cirrus cloud computing testbed: Federated data centers for open sourcesystems and services research," in The USENIX Hotcloud 2009, 2009.

7. R. P. T. F. S. Ostermann, K. Plankensteiner, "Groudsim: an eventbased simulation framework for computational grids and clouds," in CoreGRID/ERCIM Workshop on Grids and Clouds. Springer Computer Science Editorial, Ischia, 2010. 2010.

8. D. R. M. P. Jain;, "Study and comparison of various cloud simulators available in the cloud computing," in International Journal of Advanced Research in Computer Science and 
Software Engineering, vol. 3, no. 9, September 20

9. Collin Bennett, Robert Grossman and Jonathan Seidman, “Malstone: A Benchmark for Data Intensive Computing", Open Cloud Consortium Technical Report TR--09--01, 14 April 2009 Revised 1 June 2009

10. C. Bennett, R. L. Grossman, D. Locke, J. Seidman, and S. Vejcik, "MalStone: Towards a Benchmark for Analytics on Large Data Clouds," in Proceedings of the 16th ACM International Conference on Knowledge Discovery and Data mining (SIGKDD '10), 2010, pp. $145-152$.

11. S. Ostermann, K. Plankensteiner, and D. Bodner, "Integration of an event-based simulationframework into a scientific workflow execution environment for grids and clouds", ServiceWave 2011, pp.1-13, 2011.

12. Ilango Sriram, "SPECI, a simulation tool exploring cloud-scale data centre's", CloudCom 2009, LNCS 5931, pp. 381-392, 2009, M.G. Jaatun, G. Zhao, and C. Rong (Eds.), SpringerVerlag Berlin Heidelberg, 2009

13. Simon Ostermann, Kassian Plankensteiner, Radu Prodan, and Thomas Fahringer, "GroudSim: An Event Based Simulation Framework for Computational Grids and Clouds", M.R. Guarracino et al. (Eds.): Euro-Par 2010 Workshops, pp. 305-313, 2011. Springer- Verlag Berlin Heidelberg, 2011

14. S. Ostermann, K. Plankensteiner, and D. Bodner, "Integration of an event--based simulationframework into a scientific workflow execution environment for grids and clouds", ServiceWave 2011, LNCS 6994, pp.1-13, 2011.

15. T. Fahringer, R. Prodan, R. Duan, et al., "ASKALON: a grid application development and computing environment," 6th IEEE/ACM International Conference on Grid Computing, pp.122-131, IEEE, 2005

16. F. Fittkau, S. Frey, W. Hasselbring, "Cloud user-centric enhancements of the simulator cloudsim to improve cloud deployment option analysis", Proceedings of the 1st European conference on Service-Oriented and Cloud Computing, ESOCC'12, 2012.

17. Y. Jararweh, Z. Alshara, M. Jarrah, M. Kharbutli, M. Alsaleh, "Teachcloud: a cloud computing educational toolkit", Proceedings of the 1st International IBM Cloud Academy Conference (ICA CON 2012), IBM, Research Triangle Park, NC, USA, 2012.

18. A. Nunez, J.L. Vazquez-Poletti, A.C. Caminero, G.G. Castane, J. Carretero, I.M. Llorente, "iCanCloud: a flexible and scalable cloud infrastructure simulator", Journal of Grid Computing 10:1, 2012, page:185-209.

19. A. Nunez, J.L. Vazquez-Poletti, A.C. Caminero, J. Carretero, I.M. Llorente, "Design of a new cloud computing simulation platform", Proceedings of the International conference on Computational science and its applications, ICCSA'11, Santander, Spain, 2011, pp. 582-593.

20. FlexCloud: A Flexible and Extendible Simulator for Performance Evaluation of Virtual Machine Allocation Minxian Xu, Wenhong Tian, Xinyang Wang, Qin Xiong Dr. Tian, Mr. Wang and Miss Xiong are in the school of Computer Science, University of Electronic Science and Technology of China (UESTC), 610054; Mr. Xu is in the school of software engineering of UESTC.

21. GloudSim: Google Trace based Cloud Simulator with Virtual Machines by Sheng Di, Franck Cappello 1INRIA, Argonne National Laboratory, USA

22. DCSim: "A Data Centre Simulation Tool"- Gaston Keller, Michael Tighe, Hanan Lutfiyya and Michael Bauer -' 2013 IFIP/IEEE International Symposium on Integrated Network Management (IM2013).
Comparative Analysis of Cloud Simulators and Authentication Techniques in Cloud Computing 